\title{
Emerging Trends in Employee Retention Strategies in a Globalizing Economy: Nigeria in Focus
}

\author{
Izidor Nwokocha $^{1} \&$ E. B. J. Iheriohanma ${ }^{2}$ \\ ${ }^{1}$ Department of Sociology/Anthropology, Ebonyi State University, Abakaliki, Nigeria \\ ${ }^{2}$ Directorate of General Studies, Federal University of Technology, Owerri, Nigeria \\ Correspondence: E. B. J. Iheriohanma, Directorate of General Studies, Federal University of Technology, Owerri \\ P. M. B. 1526, Owerri, Imo State, Nigeria. E-mail: iherioha2005@yahoo.com
}

Received: April 10, 2012

Accepted: May 12, $2012 \quad$ Published: August 1, 2012

doi:10.5539/ass.v8n10p198

URL: http://dx.doi.org/10.5539/ass.v8n10p198

\begin{abstract}
This study explores the emerging trends in employee retention strategies in a globalizing economy, with a focus on Nigeria. The paper argues that globalization has enhanced the mobility of labor, and has also accelerated the rate of employee turnover in organizations in Nigeria. The paper identifies some of the reasons for turnover to include inequity in the compensation packages of organizations, employees' dissatisfaction and autocratic managerial pattern in most organizations in Nigeria. It further identifies the effects of turnover to include disruption in production, cost of training new employees, the recruitment and selection cost and knowledge lost. As a panacea to minimize the rate of employee turnover and catch up with the current demands of global economic needs and organizational performance, the study proposes that organizations in Nigeria should adopt critical sustainable retention trends such as establishing a strategic plan, involving employees in decision-making process, initiating personalized compensation plan, installing mechanisms for career planning, training and development and building flexible work programs especially for critical knowledge - employees. These will help to retain core employees that will competitively drive the production wheel in the organizations in Nigeria in this era of globalization.
\end{abstract}

Keywords: globalization, employee turnover, emerging trends, employee retention strategies, Nigeria

\section{Introduction}

The emerging trend in today's fast-changing competitive business environment occasioned by globalization has presented evident challenges before the Human Resources professionals. With increasing globalization, there have been enormous and far reaching changes in global organizations. These changes are the result of fierce international competitive pressure faced by enterprises operating in the global place encircled with knowledge driven productive economy (Wokoma and Iheriohanma, 2010).

The new demands of international competitive and dramatic advances in information and communications technologies (ICT), and new patterns of consumer demands for goods and services have propelled organizations across the world to change substantially and adopt new methods of production and organization of work. This situation has tremendously enhanced the mobility of individuals, thereby accelerating the rate of employee turnover in organizations. As a result, the recruitment of competent personnel equipped with the requisite knowledge has increasingly been difficult in Nigeria.

Employee commitment, productivity and retention issues are emerging as the most critical challenge on the management of workforce in the immediate future. This challenge is driven by the concerns of employee loyalty, corporate restructuring efforts and tight competition for key talents (Kresiman, 2002). For many firms, employee departures can have significant effects on the execution of business plans and may eventually cause a parallel decline in productivity. This phenomenon is especially true in the light of current economic uncertainty and following corporate downsizing, as occasioned by outsourcing and other intricate production dictates. The impact of losing critical employees increases exponentially (Noer, 1993; Ambrose, 1996; Caplan and Teese, 1997). This is so because every economy relies on the capacity and knowledge - competence of its human resource for economic development. Hence, human resource is the greatest asset of any organization. 
Globally, the retention of skilled employees has been a serious concern to management. The desired critical measures for retention of employees have therefore become strategic to sustainable competition among organizations in a globalizing economy such as Nigeria. This development has dramatically changed human resource practice in the area of attracting skilled employees into organizations, and most importantly is the strategy for retaining them (Samuel, 2008; Nwokocha, 2012).

Employee retention connotes the means, plan or set of decision-making behavior put in place by organizations to retain their competent workforce for performance (Gberevbie, 2008). There have been many human resource strategies provided to retain employees for the advantage of the organizations. These strategies are aimed at avoiding employee turnover. Mobley (1982) defines turnover as the cessation of membership in an organization by individuals who have received monetary compensation from the organization.

Organizations rely on the expertise, knowledge, skills, and capital resource and capacity development of their employees in order to compete favorably and indeed gain competitive advantage in the international market. However, recent studies have shown that retention of highly skilled employees has become a difficult task for managers, as this category of employees are being attracted by more than one organization at a time with various kinds of incentives (Micheal, 2009). This behooves on management to create an enabling and sustainable critical culture and strategies to work out retention systems and structures for their existing core employees in these contemporary organizations. This is pertinent because according to Czkan (2005), the motivational strategies used to attain retention in the past are or may no longer be appropriate to motivate critically talented and mobile employees to remain, thereby increasing the rate of turnover.

It is against this backdrop that this paper intends:

(a) To examine the traditional employee retention strategies in organizations, especially in Nigeria,

(b) To illuminate on the factors responsible for an observed rising rate of turnover in organizations in Nigeria,

(c) To highlight the effects of turnover on organizations,

(d) To explore the emerging trends in employee retention strategies that will be sustainable, especially in organizations in Nigeria.

This article benefits copiously from library research, informal discussions as well as personal observations of the authors. It is essentially an explorative discourse.

\section{An Overview of the Traditional Employee Retention Strategies in Organizations in Nigeria}

The intent of this sub section is to draw an insight on some of the traditional employee strategies currently being employed by most organizations in Nigeria.

\subsection{Job Satisfaction}

Job satisfaction is a general attitude toward an individual's current job. This encompasses the feelings, beliefs and thoughts about the job. Riggio (2003) describes job satisfaction as consisting of the feelings and attitudes one has about one's job. This includes all aspects of a particular job, good and bad, positive and negative, which are likely to contribute to the development of feeling of satisfaction or dissatisfaction or turnover intentions. This conforms to the views of Kim, Leong, and Lee (2005) and Scherman, Alper, and Wolfson (2006). They agreed that job satisfaction entails what employees' feel and perceive about their jobs and what their experiences on work are. Yang (2009) described job satisfaction as the agreeable emotional condition resulting from the assessment of one's job as attaining or facilitating the accomplishment of one's job values.

Job satisfaction can be influenced by a variety of factors, such as pay practice, quality of workers' relationship with their supervisor, and quality of the physical environment in which they work (Hamdia and Phadett, 2011). Job satisfaction and turnover are basically related to the extent that job satisfaction has direct effect on employee retention and turnover. Al-Hussami (2008) affirmed that if employees are more satisfied with their job, it will enhance their ability of creativity and productivity. This will in turn impart on their intention to remain in the organization. This simply suggests that employees who are satisfied with their jobs are likely to remain with the organization longer than those who are dissatisfied with their jobs. It also implies that employee retention can be achieved and turnover minimized if management is able to identify and apply appropriate variables that will create job satisfaction amongst employees. 


\subsection{Training}

Training is referred to as a planned effort to facilitate the learning of job-related knowledge, skills and behavior by employee (Noe, Holleneck, Gerhart, and Wright, 2006). Wan (2007) posits that the only strategy for organizations to radically improve workforce productivity and enhance their retention is to seek to optimize their workforce through comprehensive training and development. To achieve this purpose, organizations will have to invest on their employees to acquire the requisite knowledge, skills and competencies that will enable them function effectively in a rapidly changing and complex work environment. Batt (2002) argues that high-involvement practices such as autonomy, team collaboration, and training are related to reduce employee turnover and increase productivity.

Employees consider training, education and development as crucial to their overall career growth and goal attainment and will be motivated to remain and build a career path in an organization that offers them such opportunity (Samuel, 2008). A study by Babakus, Yavas, Karatepe and Avci (2003), reports that an organization that provides training sends a strong signal to its employees regarding management commitment to their retention and customer service. The study by Steel, Griffeth, and Hom (2002) reveals that empirical data show that lack of training and promotional opportunities were the most frequently cited reasons for high performers to leave the company. Also, the study by Bradley, Petrescu and Simmons (2004) reports that an increase in high-performance work practices is as a result of training which is converted to a decrease in employee turnover in organization. This implies that when an organization provides training to its employees, it will, to a large extent, reduce turnover and enhance employee retention.

\subsection{Reward Strategy}

According to Agarwal (1998), reward is defined as something that an organization gives to the employees in response to their contributions and performance and also something which is desired by the employees. A reward can be extrinsic or intrinsic. The extrinsic variables include company policies, co-workers relationship, supervisory styles, salary, work conditions and security. The intrinsic variables include achievement, recognition, work itself, responsibility, advancement and growth (Bassett-Jones and LIoyed, 2005). Reward can be in form of cash, bonuses, and recognition amidst others.

The purpose of reward strategy is to develop policies and practices which will attract, retain and motivate high quality people (Armstrong, 2003). The result by Taplin, Winterton, and Winterton (2003), confirmed that rewards, as provided by organizations, have positive relationship with job satisfaction and employee retention. This simply suggests that a high level of pay or benefits relative to that of competitors can ensure that an organization attracts and retains high quality employees.

\subsection{Supervisory Support}

The immediate supervisor is very important in organizational change. When a supervisor provides mentoring, the relationship affects the protégés skill development and intentions to remain with the employer (Atif, Kashif, Ijaz, Muhammad and Asad, 2011). When an employee's skill improves, it will positively affect productivity in organization. Conversely, non-supervisory mentor may increase mentee's confidence by providing access to outside organization (Scanduraa and Williams, 2004). A study by Karasek and Theorell (1990) reveals that poor supervision not only caused the dissatisfaction of employees with their work, but also instigated turnover. Keashly and Jagatic (2002) opine that poor supervision leads to dissatisfaction of employees hence the propensity for turnover. Harmon, Scott, Behson, Farias, Petzel, Neuman and Keashly (2007) in their work, argue that the control work practices which are supervision - oriented and supportive significantly correlated with increased job satisfaction and lower turnover rates among the workers.

Literature that supports social and organizational culture indicates that whenever a subordinate is properly supported by supervisor, this will generate positive outcomes both for the organization and the employee (Shanock and Eisenberger, 2006). Simth (2005), in his contribution posits that this is also beneficial for supervisor, because the more competent and more supportive the supervisor is, the more likely the employees and supervisors retain their jobs. He further states that supportive supervision enhances impact on both organizational commitment and job retention. This will in turn impart on productivity in the organization.

\section{Reasons for Employee Turnover in Organizations}

The phenomenon of turnover is of interest to organizations and theorists because it is significant, potentially costly and relatively clear cut (Mobley, 1977; Price, 1977; Lazear, 2000). Employee turnover is defined as the rotation of workers around the labour market; between the status of employment and unemployment (Abassi and Hollman, 2000). 
Turnover in organizations has not so far proved amenable to prediction. Despite an enormous literature on turnover in organizations, the concept has no universally accepted reason or framework for why employees choose to leave their organizations. However, employee turnover has been classified into two categories: voluntary and involuntary turnover. Voluntary turnover takes place when competent and capable employees particularly leave an organization to work elsewhere. This turnover is costly to the organization, because losing a valued employee reduces organizational productivity, increases expenses associated with recruitment, hiring and training a replacement and also provides an opportunity to competitors to utilize the skills, abilities and critical knowledge of an experienced and competent employee (www.psychologyybhu.blogspot.com/employee-retention). Involuntary turnover occurs when an employee is fired or laid off. A certain amount of involuntary turnover is likely to be considered inevitable, and possibly even beneficial. For instance, firing workers who are not performing at desirable levels can be viewed as positive (Mobley, 1982). This type of turnover enhances the effectiveness of the organization.

Organizational researchers have advanced many factors as being responsible for employee turnover. Sherratt (2000) and Van Vianen, Feji, Krauz, and Taris (2004) have distinguished two motives for turnover; the push and pull motives. The pull motives include inequity in compensation of an organization, the availability of opportunities to improve one's career opportunities on the external labor market and resignation by employees from organization to go into private business. The push motives are related to dissatisfaction with employee's current work situation, autocratic managerial patterns and job stress. Sometimes, it could be the combination of the two motives that propel an employee to seek for an alternative employment.

Griffieth, Hom and Gaertner (2000) posited that pay and pay-related variables have a modest effect on turnover. Their analysis also included studies that examined the relationship between pay, a person's performance and turnover. They concluded that when high performers are insufficiently rewarded, they quit. It suggests that if a job provides adequate financial incentives, the more likely employees remain with organizations and vice versa. In the views of Abassi et.al (2000), poor hiring practices, managerial style, lack of recognition, lack of competitive system in the organizations and toxic workplace environment also account for employee turnover in organizations. It is evident from this review, that many factors are responsible for turnover in organizations. It further suggests an economic indicator for stiff competition, which organizations need to change in their corporate strategies to retain their talented employees. In other words, employers need to understand their rates of labor turnover and how they affect the organizations' performance. An appreciation of the levels of turnover across occupations, locations and particular groups of employees can help inform a comprehensive resourcing strategy (www.cipd.co.uk/hr-topics/retention-turnover).

\section{Effects of Turnover on Organizations}

Employee turnover is costly and seemingly intractable human resource challenges confronting several organizations globally. The major factor of employee turnover that impinges on organizations is the costs. These costs include search of external labor market for possible substitute, selection between competing substitutes, induction of the chosen substitute, and formal and informal training of the substitute until he attains performance levels equivalent to the individual who quits (John, 2000). There are also indirect costs that are also involved when an employee leaves the organization. These, according to Sutherland (2004), include the knowledge, skills and contacts that the departing employee takes out of the organization. Gaia and Christopher (2007), posit that turnover affects both employees and organizations. Workers experience disruption, the need to learn new job-specific skills and find different career prospects. From organizational perspective, organization suffers the loss of job-specific skills, disruption in production and incurs costs of hiring and training new workers. All these affect the profitability of the organization.

Researchers have argued that high turnover rates might have negative effects on the profitability of organizations if not managed properly (Hogan, 1992; Wasmuth and Davis, 1993; and Barrows, 1990). Turnover also makes it difficult for organizations to maintain a steady and successful operation. Research estimates that hiring and training a replacement worker for a lost employee costs approximately 50 percent of the worker's annual salary (Johnson, Griffeth and Griffin, 2000; and Susan, 2011). Each time an employee leaves the organization, productivity drops due to the learning curve involved in understanding the job and the organization. Also, the loss of critical and irreplaceable intellectual capital adds to these costs, since not only do organizations lose the human capital and relational capital of the departing employee, but other competitors are potentially gaining these critical assets (Meaghan and Nick, 2002). It is therefore suggested that since turnover is an index of organizational effectiveness, it then requires the attention and comprehensive understanding of information on turnover. This will be relevant for planning, prediction and control of resources for organizational managers to check mate the effects associated with turnover in the organization, especially in Nigeria. 


\section{Emerging Trends in Employee Retention Strategies}

The fierce competition globally for qualified workforce has made it pertinent for organizations to radically alter and initiate new workplace trends that will provide for sustainable and attractive retention strategies for their critically talented employees. This is so, because as business growth continues to move to the forefront, people issues are becoming even more critical as organizations seek for skilled people to handle the growth. Nigeria, being part of the global environment is not excluded in this quest. Hence, this section seeks to explore the emerging trends in employee retention strategies that will be sustainable, with specific focus on Nigeria. This will be addressed on the following sub headings:

- Establishment of strategic retention plan

- Employee participation in decision-making

- Personalized compensation plan

- Career planning, training and development programs

- Creation of work flexibility and outsourcing strategy

\subsection{Establishment of Strategic Retention Plan}

For organizations to compete favorably in this business world that is characterized by increased global competition and tensed business area, it is imperative that management of organizations in Nigeria should design strategic retention programs that will align and integrate their choice employees into the organization. This should be done by aligning the organization's human capital processes with its overall business strategy. This entails elevating the retention strategies to a more strategic level which in turn yields indisputable business benefits and employee's satisfaction to remain with the organization. In doing this, organizations must regularly analyze the effectiveness of these strategies, making sure that all employees data are captured and aligned. This will help increase the efficiency of the program and also serve as an early warning sign for problem areas (www.ey.com).

\subsection{Participatory Decision-Making Process}

The challenging trends in the competitive global economic market and workplace require organizations to involve the participation of workers in the decision-making process of the organizations in order to retain their critical employees and to secure their loyalty, commitment, dedication and ensure their security. This involves the integration of these choice employees in organizational participation, management and administration that will usher in industrial and organizational efficiency and harmony. Iheriohanma (2008) posits that:

Workers in Nigeria desire security of their jobs in their workplace. They desire affection and interaction with colleagues, they want to be recognized, assured of their work life. They want to achieve and prove their competence. These and more can be realized if they are informed, accommodated and integrated in the formulation of policies that guide their work processes.

The need to involve critical employees into decision-making process cannot be over emphasized. Nigerian workers are exposed to workplace issues like their counterpart all over the world. This is occasioned by the advent of Information and Communications Technology (ICT) which has made the world a one global village, which has lead to the cross fertilization of ideas amongst the workers worldwide. Participatory management is a power-sharing mechanism under which both managers and workers, in an accommodating, cooperative and complementary manner, do their jobs better. It gives workers some personal voice in the decisions that govern their workplace (Iheriohanma, 2007). The implication here is that, when workers are integrated into the decision-making process of the organization, they will feel valued, accommodated and this will stifle or blur their intentions to leave or quit the organization.

Creating the atmosphere for participatory management also entails initiating a more humane work environment that will appreciate the contributions of the workers in the organization. This requires the displacement of authoritarian management style that will involve the re-orientation of managerial attitude to reflect a transactional culture in workplace. This also encourages the cultivation of unsuspicious partnership and collaborative teamwork with employees that will help to stimulate a pleasant social work environment that will respond expediently to employee needs and complaints. This relaxed social atmosphere includes a friendly and happy environment reminiscent of a family. This underscores the views of Cappeli (2000) and Michell, Holton and Lee (2001), that social friendship at work acts as drivers to enduring employee retention in the organization. 


\subsection{Personalized Compensation Plan}

According to Samuel (2008), money acts as a "scorecard" which enables employees to assess the value the organization places on them in comparison to others. In this context, organizations are required to devise sustainable compensation strategies that will cover the broad spectrum of total compensation, not just basic pay and salary, but including performance - based and special recognition programs to its critical employees. The pay should be equitably comparative to the ones prevailing outside and within the industry for similar jobs. In devising this personalized compensation plan for critical employees in the organization, the plan should cover many diverse compensation techniques like competitive salary, project bonus, superannuation and fringe benefits. In this way, it is believed that employees would be adequately motivated and would resist the temptation of leaving the organization (Davar, 2003). This will in turn, propel the workers into better performance that will enhance productivity in the organization.

\subsection{Career Planning, Training and Development}

Career development is a system which is organized and formalized, and it is a planned effort towards achieving a balance between the individual career needs and the organization's workforce requirement. Opportunities for career development are considered as one of the most important factors affecting employee retention.

It is suggested that a company that wants to strengthen its bond with its employees must invest in the training and development of these employees (Hall and Moss, 1998; Woodruffe, 1999; Steel, Griffeth, and Hom, 2002; Hsu, Jiang, Klein, Tang, 2003). This entails creating opportunities for promotion within the company and also providing opportunities for training and critical skills development that allows employees to improve their employability competitively on the internal and/or external labor market (Butler and Waldrop, 2001). Wan (2007) argues that the only strategy for organizations to radically improve workforce productivity and enhance their retention is to seek to optimize their workforce through comprehensive training and development. To achieve this purpose, organizations will have to invest on their employees to acquire the requisite critical knowledge, skills and competencies that will enable them function effectively in a rapidly changing and complex work environment. This simply suggests that human resource is central to the accomplishment of organizational goals and objectives. Knowledge workers are treated as assets and partners rather than costs. It is therefore, admissible that organizations in Nigeria should adapt to the changes provided by Information and Communications Technology (ICT) in order to compete in this knowledge - based and knowledge - driven economy. This is because, critical ICT-based knowledge acquisition is a veritable tool for socio-economic issues that challenge production and influence behavior in the workplace (Iheriohanma, 2008). Employees consider training, education and development as crucial to their overall career growth, development and goal attainment and will be motivated to remain and build a career path in an organization that offers them such opportunities (Samuel, 2008). Most organizations lose their talented workers through inefficient career planning. By failing to focus on talent management programs specifically on core employees, organizations stand the risk of losing valuable skills to competitors and waste their investment.

Instituting mechanisms for career planning, training and development of human capital in the organization is therefore suggested. There is also the need for a vibrant and resource - oriented Human Resource manager with a well equipped personnel department. This will lay the foundation for new skills that will ensure that competitive advantage is gained through people and this will result to increased corporate productivity in this globalised economy.

\subsection{Creation of Work Flexibility and Outsourcing Strategy}

Creation of work flexibility entails work-life balance in the organization. Work-life balance is an efficient tool by which every employee is given an opportunity to choose time out during work hours. It is a policy that defines how the organization intends to allow what they do at work to align with the responsibilities and interests they have outside (Armstrong, 2003). Work-life balance is necessary because the current employees attach much importance to quality of life due to the ever increasing work pressure (Cappelli, 2001; Michell, Holton, and Lee, 2001). In the same vein, outsourcing provides organizations the challenging opportunity to fan out jobs to specialist firms and contractors at little or no cost and burden thereby creating enough space and time for their employees to concentrate on the ones they have competence and comparative advantage on. By applying work-life course of actions and outsourcing, an organization can enhance its ability to respond to demands of customers for better access to services and provide the tactics for the organizations to deal with the revolutionized way in order to satisfy both employees and employers (Manfredi and Holliday, 2004). The application of work flexibility and outsourcing in organizations, especially complex organizations and multinationals, will impact on employee retention and minimize rate of turnover, especially in this knowledge - 
driven economy. This is because there is greater organizational commitment, harmony and improved productivity if employees are accorded access to work-life balance.

The adoption of the afore-mentioned sustainable strategies will provide a roadmap for balancing the needs of the organizations with those of its knowledge - employees as well as address the human capital issues that will challenge the competitiveness in this globalized society. Organizations in Nigeria will benefit copiously if they adopt these critical strategies to encourage commitment and security of their employees. The availability, use and pervasiveness of ICT in work life make the adoption of the above strategies imperative to avert employee turnover, encourage retention of, especially high ability and knowledge - workers and to improve productivity.

\section{Conclusion}

This study revealed the need for sustainable retention strategies in organizations in Nigeria. It took into consideration the competitive business environment that is occasioned by globalization. This is inferred from the effects associated with employee turnover in organizations, which express the inadequacies in the traditional retention strategies in organizations in Nigeria. The study therefore, proposes that organizations in Nigeria should adopt certain critical sustainable trends in employee retention such as, establishment of strategic retention plan, involvement of employees in decision-making process, personalized compensation plan, career planning, training and development and creation of work flexibility and outsourcing. This is pertinent if these organizations want to catch up with the current demands of global economic needs which require the use of talented workforce to drive the fundamental changes and production processes that are taking place in work organizations globally.

\section{References}

Abassi, S. M., \& Hollman, K. W. (2000). Turnover: The Real Bottom Line. Public Personnel Management, 2(3), 233-342.

Agarwal, N. C. (1998). Reward Systems: Emerging Trends and Issues. Canadian Psychology, 39(1), 60-70. http://dx.doi.org/10.1037/h0086795

Al-Hussami, M. (2008). A Study of Nurses'Job Satisfaction: the Relationship to Organizational Commitment, Perceived Organizational Support, Transactional Leadership, Transformational Leadership, and Level of Education. European Journal of Science Resource, 22(22), 286-295.

Ambrose, D. (1996). Healing the Downsized Organization. New York: Three Rivers Press.

Armstrong, M. (2003). A Handbook of Human Resource Management Practice. London: Kogan Page Limited

Atif, A., Kashif, U. R., Ijaz, U. R., Muhammad, A. K., \& Asad A. H. (2011). Impact of Organizational Commitment on Job Satisfaction and Employee in Pharmaceutical Industry. African Journal of Business Management, 5(17), 7316-7324.

Babakus, E., Yavas, U., Karatepe, O., \& Avci, T. (2003). The Effect of Management Comment to Service Quality on Employees' Effective Performance Outcomes. Academy of Marketing Science, 31(3), 272-287. http://dx.doi.org/10.1177/0092070303031003005

Barrows, C. (1990). Employee Turnover: Implications for Hotel Manager. FIU Hospital Review, 24-31.

Bassett-Jones, N., \& LIoyd, G. C. (2005). Does Herzberg's Motivation Theory have Staying Power? Journal of Management Development, 24(10), 929-943. http://dx.doi.org/10.1108/02621710510627064

Batt, R. (2002). Managing Customer Services: HR Practices, Quit Rates and Sales Growth. Academy of Management Journal, 45, 587-601. http://dx.doi.org/10.2307/3069383

Bradley, S; Petrescu, A., \& Simmons, R. (2004). The Impacts of Human Resources Management Practices and Pay Inequality on Workers'Job Satisfaction. Paper presented at the Western Economic Association 79th Annual Conference Vancouve.

Butler, T., \& Waldrop, J. (2001). Job Sculpting: The Art of Retaining your Best People \& Harvard Business Review on Finding and Keeping the Best People. Boston: Harvard Business School Press.

Campell, P. (2000). Managing Without Commitment. Organizational Dynamics, 28(4), 11-24. http://dx.doi.org/10.1016/S0090-2616(00)00008-5

Caplan, G., \& Teese, M. (1997). Survivors - How to keep Your Best People on Board after Downsizing. Palo Alto, CA: Davis- Black Publishing.

Czakan, T. (2005). Talent Scouting: The Dynamics of Top Talent. Journal of the South African Institute of People 
Management, 23(3), 8-9.

Davar, R. S. (2003). Personnel Management and Industrial Relations. New Delhi: Vikas Publishing House PVT Limited.

Employee Retention: A Challenge for HR Practitioners. Retrieved September 27, 2011, from http://www.psychologyofbhu .blogspot.com/employee-retention

Gaia, G., \& Christopher, M. (2007). The Impact of Labour Turnover: Theory and Evidence from UK Micro- Data, University of Leicester, Dept of Economic. Working Paper No. 05/10.

Gberevbie, D. E. (2008). Staff Recruitment, Retention Strategies and Performance of Selected Public and Private Organizations in Nigeria. Unpublished Ph.D Thesis. Covenant University, Ota.

Griffeth, R. W., Hom, P. W., \& Gaertner, S. (2000). A Meta-Analysis of Antecedents and Correlates of Employee Turnover: Update, Moderator Tests, and Research Implication for Next Millennium. Journal of Management, 26(3), 463-488. http://dx.doi.org/10.1177/014920630002600305

Hall, D. T., \& Moss, J. E. (1998). The New Protean Career Contract: Helping Organizations and Employees Adaption. Organizational Dynamics, 26(3), 22-37. http://dx.doi.org/10.1016/S0090-2616(98)90012-2

Hamidia, M., \& Phadeff, T. (2011). Conceptual Framework on the Relation Between Human Resource Management Practices, Job Satisfaction, and Turnover. Journal of Economics and Behavioral Studies, 2(2) 41-49.

Harmon, J., Scott, D. J., Behson, S., Farias, G., Petzel, R., Neuman, J. H., \& Keashly, L. (2007). Effects of High Involvement of Work Systems on Employee Satisfaction and Services Costs in Veterans Healthcare. Journal of Healthcare Management, 48(6), 1-14.

Hogan, J. J. (1992). Turnover and What to Do About it. The Cornell HRA Quarterly, 33(1), 40-45.

Hsu, M.K., Jiang, J. J., Klein, G., \& Tang, Z. (2003). Perceived Career Incentives and Intent to Leave. Information and Management Journal, 40, 361-369. http://dx.doi.org/10.1016/S0378-7206(02)00018-6

Iheriohanma, E. B. J. (2007). The Socio-Economic Issues Challenging Workers' Participation in Management and Productivity in Nigeria. IKOGHO: A Multi-Disciplinary Journal, 4(4), 1-11.

Iheriohanma, E. B. J. (2008). Linkage Between Participatory Management, Managerial Efficiency and Productivity in the Nigeria Civil Service. IKOGHO: A Multi-Disciplinary Journal, 5(1), 56-62.

John, S. (2000). Job-to-Job Turnover and Job to-Non- Employment Movement. Personnel Review, 31(6), 710-721.

Johnson, J., Griffeth R.W., \& Griffin, M. (2000). Factors Discrimination Functional and Dysfunctional Sales Force Turnover. Journal of Business Industrial Market, 15(6), $399-415$. http://dx.doi.org/10.1108/08858620010349493

Karasek, R., \& Theorell, T. (1990). Healthy Work: Stress, Productivity, and the Reconstruction of Working Life. New York: Basic Books.

Keashly, L., \& Jagatic, K. (2000). The Nature and Extent of Emotional Abuse at Work: Results of a Statewide Survey. Paper Presented at the Symposium on Persistent Patterns of Aggressive Behaviour at work. Academy of Management Annual Meeting, Toronto, Canada.

Kim, W. G., Leong, J. K., \& Lee, Y. (2005). Effect of Service Orientation on Job Satisfaction, Organizational Commitment, and Intention of Leaving in a Casual Dining Chain Restaurant. Hospitality Management, 24 , 171-193. http://dx.doi.org/10.1016/j.ijhm.2004.05.004

Kreisman, B. J (2002). Identification of the Drivers of Employee Dissatisfaction and Turnover. Unpublished Doctoral Dissertation. Austin Texas: University.

Lazear, E. (2000). Performance Pay and Productivity. American Economic Review, 90, $1346-1361$. http://dx.doi.org/10.1257/aer.90.5.1346

Managing Today's Global Workforce. Retrieved March 19, 2012, from http://www.ey.com

Manfredi, S., \& Holliday, M. (2004). Work-life Balance: An Audit of Staff Experience at Oxford Brooks University. Centre for Diversity Policy Research. Oxford: Oxford Brooks University Press.

Meaghan, S., \& Nick, B. (2002). Voluntary Turnover: Knowledge Management-Friend or Foe? Journal of Intellectual Capital, 3(3), 303- 322. http://dx.doi.org/10.1108/14691930210435633 
Micheal, O. S. (2009). Employee Retention and Turnover: Using Motivational Variables as Panacea. African Journal of Business Management, 3(8), 410-415.

Mitchell, T. R., Holtom, B. C., \& Lee, T. W. (2001). How to Keep Your Best Employees: Developing an Effective Retention Policy. Academy of Management Executive, 15(4), 96-109. http://dx.doi.org/10.5465/AME.2001.5897929

Mobley, W. H. (1977). Intermediate Linkages in the Relationship Between Job Satisfaction and Employee Turnover. Journal of Applied Psychology, 62, 238- 245. http://dx.doi.org/10.1037/0021-9010.62.2.237

Mobley, W. H. (1982). Employee Turnover: Causes, Consequences and Control. Menlo Park, CA: Addision-Wesley.

Noe, R. A., Hollenbeck, J. R., Gerhart, B., \& Wright. P. M. (2006). Human Resources Management: Gaining a Competitive Advantage. New York: McGraw-Hill/Irwin.

Noer, D. (1993). Healing the Wounds - Overcoming the Trauma of Layoffs and Revitalizing Downsized Organizations. San Francisco: Jossey-Bass.

Nwokocha, I. (2012). Exploration of Sustainable Managerial Strategies for Employee Retention in the Private Sector Organizations in Nigeria: A Study of Selected Organizations in Port Harcourt, Nigeria, Paper presented at the Postgraduate Seminar Series, Ebonyi State University, Abakaliki, Nigeria.

Price, J. L. (1977). The Study of Turnover. Iowa University Press.

Retention and Turnover. Retrieved March 5, 2012, from http://www.cipd.co.uk/hr-topics/retention-turnover

Riggio, R. E. (2003). Introduction to Industrial Organizational Psychology. New Jersey: Pearson Education.

Samuel, O. M. (2008). Using Motivational Strategy as Panacea for Employee Retention and Turnover in Selected Public and Private Sector Organizations in Eastern Cape Province of South Africa. Unpublished M.Sc Thesis, University of Fort Hare.

Scanduraa, T. A., \& Williams, E. A. (2004). Mentoring and Transformational Leadership: The Role of Supervisory Career Mentoring. Journal of Vocational Behaviour, 65, 448-468. http://dx.doi.org/10.1016/j.jvb.2003.10.003

Shanock, L.R., \& Eijenberger, R. (2006). When Supervisors Feel Supported: Relationships with Subordinates' Perceived Supervisor Support, Perceived Organizational Support, and Performance. Journal of Applied Psychology, 91(3), 689-695. http://dx.doi.org/10.1037/0021-9010.91.3.689

Sherma, D., Alper, W., \& Wolfson, A. (2006). Seven Things Companies Can Do to Reduce Attrition. Journal of South African Institute of People Management, 24(3), 8-11.

Sherrat, J. (2000). Attracting and Retaining the Right Staff. Management Today Journal, 16(5), 38-39.

Smith, B. D. (2005). Job Retention in Child Welfare: Effects of Perceived Organizational Support, Supervisor Support, and Intrinsic Job Value, Children and Youth Service. Review, 27, 153-169. http://dx.doi.org/10.1016/j.childyouth.2004.08.013

Steel, R.P., Griffeth, R.W., \& Hom, P. W. (2002) Practical Retention Policy for the Practical Manager. Academy of Management Executive, 18(2), 149-169. http://dx.doi.org/10.5465/AME.2002.7173588

Susan, M. H. (2011). Top Ten Ways to Retain Your Great Employee. Retrieved September 15, 2011, from http://www.humanresource.about.com

Sutherland, M. M. (2004). Factors Affecting the Retention of Knowledge Workers. Unpublished Thesis, University of Johannesburg.

Taplin, I. M., Winterton, J., \& Winterton, R. (2003). Understanding Labour Turnover in a Labour Industry: Evidence from the British Clothing Industry. Journal of Management Studies, 40(4), 1021-1046. http://dx.doi.org/10.1111/1467-6486.00369

Van Vianen, A. E. M., Feji, J. A., Krausz, M., \& Taris, R. (2004). Personality Factors and Audit Attachment Affecting Job Employability. International Journal of Selection and Assessment, 11, 243-264.

Wan, H. L. (2007). Human Capital Development Policies: Enhancing Employees' Satisfaction. Journal of European Industrial Training, 31(4), 297-319. http://dx.doi.org/10.1108/03090590710746450

Wasmuth, W. J., \& Davis, S. W. (1993). Managing Employee Turnover; Why Employee Leave. The Cornell HRA Quarterly, 11-18. 
Wokoma, C. U., \& Iheriohanma, E. B. J. (2010). Interaction Between Globalization and Organizational Performance in the Third World: Nigeria in Focus. Studies in Sociology of Science, 1(2), 72-80.

Woodruffe, C. (1999). Winning the Talent War: A strategic Approach to Attracting, Developing and Retaining the Best People. UK: John Wiley \& Sons.

Yang, J. (2009). Antecedents and Consequences of Job Satisfaction in Hotel Industry. International Journal of Hospitality Management, 29(4), 609-619. http://dx.doi.org/10.1016/j.ijhm.2009.11.002 